\title{
Sepsis and Volume Resuscitation
}

\author{
Jozef Firment ${ }^{1 *}$, Peter Firment ${ }^{2}$, Vladimír Hudák ${ }^{1}$ and Janka Vašková ${ }^{3}$ \\ ${ }^{1}$ Department of Anaesthesiology and Intensive Medicine, Pavol Jozef Šafárik University in Košice, Slovak Republic \\ ${ }^{2}$ Department of Anaesthesiology and Intensive Medicine, JA Reiman University Hospital, Slovak Republic \\ ${ }^{3}$ Department of Medical and Clinical Biochemistry, Pavol Jozef Šafárik University in Košice, Slovak Republic
}

Submission: May 01, 2017; Published: October 27, 2017

*Corresponding author: Jozef Firment, 1st Clinic of Anaesthesiology and Intensive Medicine, Louis Pasteur University Hospital, Faculty of Medicine,

Pavol Jozef Šafárik University in Košice, Trieda SNP 104066 Košice, Slovak Republic, Email: jozef.firment@upjs.sk

\section{Abstract}

New definitions of sepsis have been published in 2016 to facilitate and refine the identification and early treatment of septic patients. One of the first steps after identifying a septic patient is to supplement circulating blood volume, monitor blood flow, and, if necessary, indicate the necessity of vasopressor support of blood circulation.

Keywords: Sepsis; Septic shock; Volume resuscitation

Abbreviations: A: Adrenaline; aPTT: Activated Partial Thromboplastin Time; AVL: Artificial Ventilation of Lungs; CO: Cardiac Output; DOB: dobutamine; DOP: Dopamine; INR: International Normalized Ratio; MAP: Mean Arterial Pressure; NA: noradrenaline; PLR: Passive Leg Raising; sBP: Systolic Blood Pressure; SIRS: Systemic Inflammatory Response Syndrome; SOFA score: Sequential Organ Failure Assessment Score; qSOFA: Quick SOFA

\section{Background}

The first comprehensive definitions of sepsis were published in 1992 [1], and subsequently reformed in 2001 [2]. Under their influence, recommendations for the diagnosis and treatment of sepsis were issued in 2004, 2008 and 2012 [3-5]. The most recent recommendations were revised during 2016 and published in early 2017 [6]. It is currently recommended to follow the Third Consensus Definition of Sepsis and Septic Shock, valid since 2016 (Sepsis-3) [7]. The shortcomings of the previous definitions were evident in the excessive emphasis on inflammation and

\section{Sepsis definitions}

Table 1: SOFA evaluation (Sequential [Sepsis-Related] Organ Failure Assessment Score).

\begin{tabular}{|c|c|c|c|c|c|}
\hline Organ / System Points: & $\mathbf{0}$ & $\mathbf{1}$ & $\mathbf{2}$ & $\mathbf{3}$ & $\mathbf{4}$ \\
\hline $\begin{array}{c}\text { Respiratory system } \\
\mathrm{paO}_{2} / \mathrm{FiO}_{2} \mathrm{paO}_{2} \text { vmmHg }(1 \mathrm{kPa}=7,5 \mathrm{mmHg})\end{array}$ & $\geq 400(53,3)$ & $<400(53,3)$ & $<300(40)$ & $<200(26,7)$ & $<100$ \\
\hline $\begin{array}{c}\text { Coagulation } \\
\text { Platelets } \mathrm{x} 103 / \mathrm{mm} 3\end{array}$ & $>150$ & $<150$ & $<100$ & $<50$ & $<20$ \\
\hline $\begin{array}{c}\text { Liver } \\
\text { Bilirubin } \mu \mathrm{mol} / \mathrm{l}\end{array}$ & $<20$ & $20-32$ & $33-101$ & $102-204$ & $>204$ \\
\hline $\begin{array}{c}\text { Cardiovascular system } \\
\text { hypotension/doses of catecholamines }\end{array}$ & MAP $\geq 70 \mathrm{mmHg}$ & MAP $<70 \mathrm{mmHg}$ & $\begin{array}{c}\text { DOP } \leq 5 \\
\text { or DOB }\end{array}$ & $\begin{array}{c}\text { DOP } 5-15 \text { or } \leq 0,1 \text { or NA } \\
\leq 0,1\end{array}$ & AOP $>15$ or \\
\hline
\end{tabular}

the disproportionate sensitivity and specificity of the SIRS criteria. The definition's indication that sepsis develops through severe sepsis into septic shock has, in practice, created unclear situations in which cases potentially treated as ambulant are instead treated as severe sepsis in the Intensive Care Unit. Also, ambiguous definitions and terminology for sepsis, septic shock and organ dysfunction have led to different incidence and mortality outcomes for these nosological units. For these reasons, a group of experts agreed that the term severe sepsis is superfluous and should not be used [6]. 


\begin{tabular}{|c|c|c|c|c|c|}
\hline $\begin{array}{c}\text { Central nervous system } \\
\text { Glasgow coma score }\end{array}$ & 15 & $14-13$ & $12-10$ & $9-6$ & $<6$ \\
\hline $\begin{array}{c}\text { Kidney } \\
\text { Creatinin }(\mu \text { mol/l) or diuresis }\end{array}$ & $<110$ & $110-170$ & $171-299$ & $\begin{array}{c}300-440 \text { or } \\
<500 \mathrm{ml} / 24 \mathrm{hr}\end{array}$ & $\begin{array}{c}>440 \mathrm{or} \\
<200 \mathrm{ml} / 24 \mathrm{hr}\end{array}$ \\
\hline
\end{tabular}

Table 2: Comparison of original and new terminology.

\begin{tabular}{|c|c|c|}
\hline Definition & Old & New \\
\hline SEPSIS & $\begin{array}{c}\text { SIRS } \\
+ \\
\text { Suspected infection }\end{array}$ & $\begin{array}{c}\text { Suspected/proven infection } \\
+ \\
2 \text { or } 3 \text { points qSOFA (HAT) } \\
\text { Hypotension }- \text { sBP }<100 \mathrm{mmHg} \\
\text { Altering the mental state } \\
\text { Tachypnea }>22 / \text { min } \\
\text { or } \\
\text { Raise SOFA scores by } 2 \text { or more points }\end{array}$ \\
\hline 更 & $\begin{array}{c}\text { Sepsis } \\
+ \\
\mathrm{sBP}<90 \text { or } \mathrm{MAP}<65 \mathrm{mmHg} \\
\text { Lactate }>2 \mathrm{mmol} / \mathrm{l} \\
\text { INR }>1,5 \text { or aPTT }>60 \text { with } \\
\text { Bilirubin }>34 \mu \mathrm{mol} / \mathrm{l} \\
\text { Diuresis }<0,5 \mathrm{ml} / \mathrm{kg} / \mathrm{h} \text { within } 2 \mathrm{~h} \\
\text { Creatinine }>177 \mu \mathrm{mol} / \mathrm{l} \\
\text { Platelets }<100 \times 10^{9} \\
\mathrm{SpO}_{2}<90 \% \text { breathing air }\end{array}$ & ---------- \\
\hline SEPTIC SHOCK & $\begin{array}{c}\text { SEPSIS } \\
+ \\
\text { Hypotension after adequate fluid resuscitation }\end{array}$ & $\begin{array}{c}\text { SEPSIS } \\
+ \\
\text { Need for vasopressors on MAP }>65 \mathrm{mmHg} \\
+ \\
\text { Lactate }>2 \mathrm{mmol} / \mathrm{l} \\
\text { after adequate fluid resuscitation }\end{array}$ \\
\hline
\end{tabular}

Sepsis is now defined as life-threatening organ failure caused by the inadequate response of the host to infection. The previous concept of sepsis, presenting SIRS due to infection, is unified with the original content of heavy sepsis, which was characterized by the failure of at least one organ system, to the wider concept of sepsis. Therefore, a patient suffering from sepsis is that with an infection present and a SOFA score elevated by at least two points. Septic shock is a subset of sepsis (meaning that sepsis criteria are met) and, in addition, there is a circulatory disorder (which can be easily identified by the need to maintain mean arterial pressure above $65 \mathrm{mmHg}$ using noradrenaline) and the additional presence of cell-metabolic changes (the simplest method of identification is the increase in lactate). The most important aspect of these circumstances is the increase in the risk of death. The abbreviated term qSOFA (quick SOFA) has been introduced into identification, and expresses simplified criteria selected from SOFA, aiming to simplify the identification of a patient whose worsening clinical condition can be caused by sepsis (Table $1 \& 2$ ).

\section{Initial resuscitation of the septic patient}

Sepsis and septic shock are urgent developments in the health state, so it is recommended to start treatment and resuscitation immediately. Resuscitation with sepsis-induced hypoperfusion should be given with at least $30 \mathrm{ml} / \mathrm{kg}$ crystalloidsintravenous for the first 3 hours. This recommendation is considered strong, but is supported by the low quality of the evaluated studies. After initial resuscitation with crystalloids, the subsequent administration of the solutions should be reassessed by frequent assessment of the haemodynamic status. If clinical examination does not lead to a clear diagnosis, further reassessment of haemodynamics, including cardiac function, is recommended 
to determine the type of shock. If possible, to reassess the response to fluid delivery, it is recommended to favour dynamic variables over static ones. For patients with septic shock requiring vasopressors, it is recommended to achieve an initial mean arterial pressure (MAP) of $65 \mathrm{mmHg}$. If there are elevated levels of blood lactate in the patient, which are considered to be markers of hypoperfusion of the tissues, it is recommended to normalise them during resuscitation.
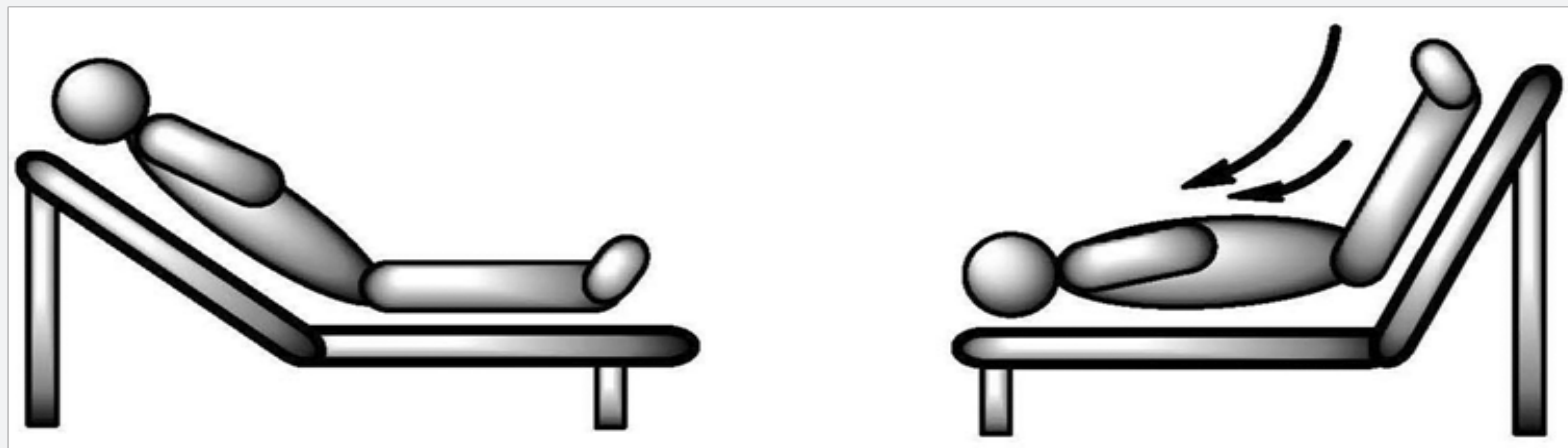

Figure 1: Passive leg raising up to $45^{\circ}$ is a simple postural manoeuvre to change the patient's position from the semirecumbent position to the final position of the passive leg raising, which should be with the trunk in the supine position and the legs with an elevation of 45 degree by means of the bed control device during the measurement of the haemodynamic indicators. With this manoeuvre, we can test whether a patient responds favourably to the administration of fluids.

Repeated re-evaluation of blood circulation response to administered solutions should include clinical examination and evaluation of static physiological variables (heart rate, blood pressure, arterial $\mathrm{pO}_{2}$, breathing, temperature, diuresis) as well as other available dynamic non-invasive or invasive methods. In practice, passive leg raising (PLR) is often used to evaluate changes in blood pressure, which can also be performed in spontaneously breathing patients. The blood that moves into the heart from the lower limbs is able to increase the preload of the left heart. The advantage of the method is also the possibility to reverse its effects by returning the patient to the semirecumbent position (Figure 1). Therefore, PLR is also referred to as "reversible autotransfusion" [8]. It should be noted, however, that the test is only orientational. It is therefore necessary to measure real-time changes in CO (echo, analysis, and curve, oesophageal doppler) for more accurate interpretation during the PLR test, and not only to provide invasive or non-invasive blood pressure measurements. $\mathrm{CO}$ must be measured continuously in real time during the test, as the effect may disappear within 1 minute [9]. Another dynamic way to evaluate hypovolaemia is to observe the fluctuations of invasively-measured arterial systolic pressure under the influence of positive pressure ventilation. The maximal increase in systolic pressure occurs at the end of inspiration and the maximum drop in systolic pressure during exspiration [8].

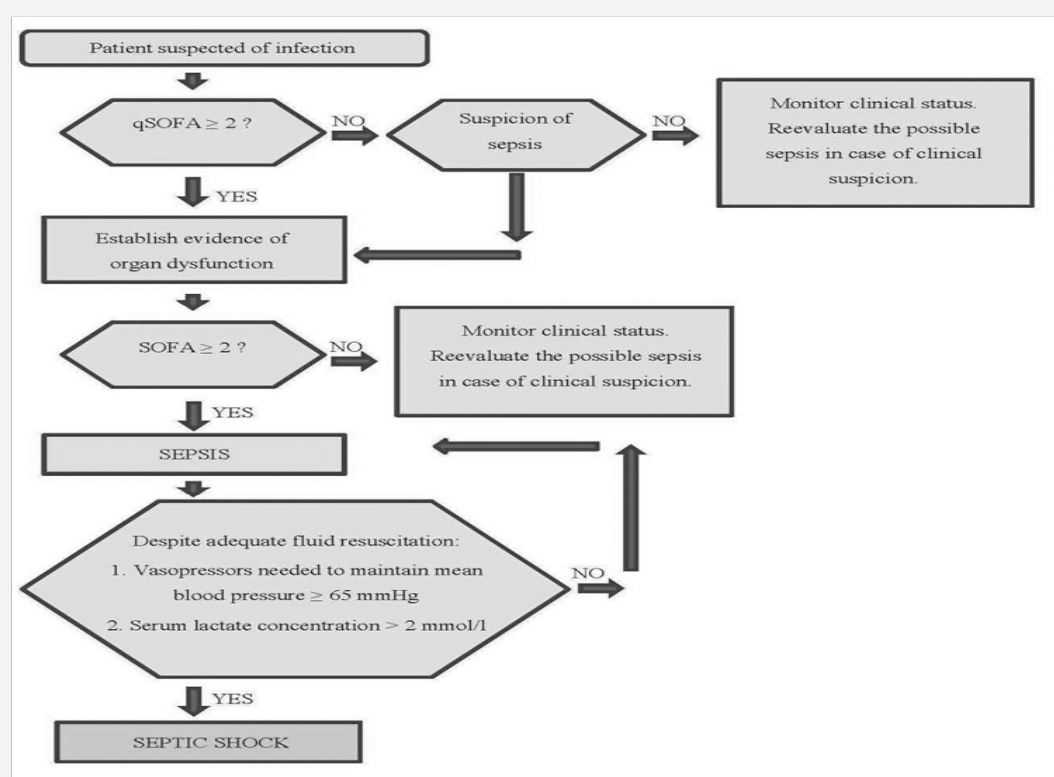

Figure 2: Clinical criteria for identifying patients with sepsis or septic shock. 
In the initial steps of treating septic shock, it is necessary to emphasize the so-called parallax MAP $65 \mathrm{mmHg}$. The rise in MAP from $65 \mathrm{mmHg}$ to $85 \mathrm{mmHg}$ after administration of NA does not significantly affect $\mathrm{O}_{2}$ metabolism, skin microcirculation, diuresis or splanchnic perfusion. The rise to $85 \mathrm{mmHg}$ from $65 \mathrm{mmHg}$ may not yet be a significant indicator of improvement. It is a picture of the macrocirculatory state (under the influence of NA): microcirculation can be closed and the shock can persist! However, if the patient worsens in the sense of decreasing MAP to $65 \mathrm{mmHg}$, it must be evaluated as a significant indicator of deterioration [10] (Figure 2).

It is still necessary to highlight the importance of lactate in the initial resuscitation of septic shock. Lactate levels serve as a more objective indicator of tissue perfusion than clinical examination or diuresis. In the resuscitation of septic shock by lactate, there is a significant decrease in mortality comparing resuscitation with and without its monitoring.

\section{Conclusion}

While it is important to add that tissue perfusion disturbances in sepsis are proven (direct microcirculation in the sublingual and intestinal tract), direct evidence that hyperlactataemia is the direct consequence of hypoperfusion of tissues is lacking and, on the contrary, the evidence does not confirm it. These studies showed a much higher level of lactate in muscle tissue compared to plasma levels in patients with hyperdynamic sepsis, despite the higher partial pressure of oxygen observed in muscle tissue by direct tissue oximetry. Could there not be a higher production of lactate for purposeful sepsis than as a consequence of hypoperfusion? Does the elevated lactate level not have any important metabolic, protective or backup functions in the stress response of the organism? A lower lactate level at the onset of the disease will result in lower insulin intensity, and early lactate reduction during treatment of sepsis will be a consequence of overall treatment and elimination of the source, or other insult (right antibiotic, early drainage of the identified abscess) $[11,12]$.

\section{Acknowledgement}

This study was supported by the VEGA no. 1/0782/15.

\section{References}

1. McCartney CJ, Brull R, Chan VW, Katz J, Abbas S, et al. (2004) Early but no long-term benefit of regional compared with general anesthesia for ambulatory hand surgery. Anesthesiology 101(2): 461-467.

2. Neal JM, Gerancher JC, Hebl JR, Ilfeld BM, McCartney CJ, et al. (2009) Upper extremity regional anesthesia. Essentials of our current understanding, 2008. Reg Anesth Pain Med 34(2): 134-170.

3. Lin E, Cho J, Hadzic A (2013) Peripheral nerve blocks for outpatient surgery: evidence-based indications. Curr Opin Anaesthsiol 26(4): 467-474.

4. Tran DQH, Russo G, Munoz L, Zaouter C, Finlayson RJ (2009) A prospective, randomized comparison between ultrasound-guided supraclavicular, infraclaviclar, and axillary brachial plexus blocks. Reg Anesth Pain Med 34(4): 366-371.
5. Perlas A, Lobo G, Lo N, Brull R, Chan VW, et al. (2009) Ultrasoundguided supraclavicular block: outcome of 510 consecutive cases. Reg Anesth Pain Med 34(2): 171-176.

6. Gauss A, Tugtekin I, Georgieff M, Dinse-Lambracht A, Keipke D, et al. (2014) Incidence of clinically symptomatic pneumothorax in ultrasound-guided infraclavicular and supraclavicular brachial plexus block. Anaesthesia 69(4): 327-336.

7. Marhofer P, Schrogendorfer K, Koinig H, Kapral S, Weinstabl C, et al. (1997) Ultrasonographic guidance improves sensory block and onset time of three-in-one blocks. Anaesth Analg 85(4): 854-857.

8. Williams SR, Chovinard P, Arcand G, Harris P, Ruel M, et al. (2003) Ultrasound guidance speeds execution and improves the quality of supraclavicular block. Anesth Analg 97(5): 1518-1523.

9. Eichenberger U, Stockli S, Marhofer P, Huber G, Willimann P, et al. (2009) Minimal local anesthetic volume for peripheral nerve block: a new ultrasound-guided nerve dimension based method. Reg Anesth Pain Med 34(3): 242-246.

10. Kubota Y, Koizumi T, Udagawa A, Kuroki T (2008) Prevention of tourniquet pain by subcutaneous injection into the posterior half of the axilla. J Plast Reconstr Aesthet Surg 61(5): 595-597.

11. Tschaikowsky K, Hemmerling T (1998) Comparison of the effect of EMLA and semicircular subcutaneous anaesthesia in the prevention of tourniquet pain during plexus block anaesthesia of the arm. Anaesthesia 53(4): 390-393

12. Winnie A (1983) Plexus Anesthesia. Philadelphia: WB Saunders.

13. Henderson JJ, Nimmo WS (1983) Practical regional Anaesthesia. Oxford: Backwell Scientic Publications.

14. Rousso M, Wexler MR, Weinberg H, Vatashky E, Aronson B (1978) Subcutaneous ring anesthesia in the prevention of tourniquet pain in hand surgery. Hand 10(3): 317-320.

15. Jóhr M, Balogh S (1998) Tourniquet pain during brachial plexus block. Anaesthesia 53(8): 828.

16. Ranganath A, Srinivasan KK, Iohom G (2014) Ultrasound guided axillary brachial plexus block. Med Ultrason16(3): 246-251.

17. Estebe JP, Davies JM, Richebe P (2011) The pneumatic tourniquet: mechanical, ischaemia-reperfusion and systemic effects. Eur J Anaesthesiol 28(6): 404-411.

18. Hagenouw RRPM, Bridenbaugh PO, van Egmond J, Stuebing R (1986) Tourniquet pain: a volunteer study. Anesth Analg 65: 1175-1180.

19. Crew JC, Cahall MA (1999) An investigation of the neurophysiologic mechanisms of tourniquet-related pain: changes in spontaneous activity and receptive field size in spinal dorsal horn neurons. Reg Anesth Pain Med 24(2): 102-109.

20. Tetzlaff JE, Yoon HJ, Walsh M (1993) Regional anaesthetic technique and the incidence of tourniquet pain. Can J Anaesth 40(7): 591-595.

21. Cole F (1952) Tourniquet pain. Anesth Analg 31: 64-65.

22. Palacios ME, Rufino J, Santiago FM, Rodríguez-Banqueri M, Gallego RJ, et al. (2005) Sciatic blockade at the level of the popliteal fossa. Comparison between two approaches. Rev Soc Esp Dolor 12: 264-268.

23. Chin KJ, Alakkad H, Cubillos JE (2013) Single, double or multipleinjection techniques for non-ultrasound guided axillary brachial plexus block in adults undergoing surgery of the lower arm. Cochrane Database Syst Rev 8: CD003842.

24. Sia S, Lepri A, Marchi M (2010) Axillary Block by “Selective” Injections at the Nerves involved in Surgery Using a Peripheral Nerve Stimulator A Comparison With a "Standard" Triple-Injection Technique. Reg Anesth Pain Med 35(1): 22-27. 
25. Silva MG, Sala-Blanch X, Marín R, Espinoza X, Arauz A, et al. (2014) Ultrasound-guided axillary block: Anatomical variations of terminal branches of the brachial plexus in relation to the brachial artery. Rev Esp Anestesiol Reanim 61(1):15-20.

26. Soodan A, Ahmad I (2010) Is a selective brachial plexus block at the axilla possible when using a nerve stimulator and large volumes of local anesthetic?. Reg Anesth Pain Med 35(5): 475-476.

27. Tran DQ, Pham K, Dugani S, Finlayson RJ (2012) A Prospective, Randomized Comparison Between Double-, Triple-, and QuadrupleInjection Ultrasound-Guided Axillary Brachial Plexus Block. Reg Anesth Pain Med 37(3): 248-253.

28. Wu CL, Naqibuddin M, Fleisher LA (2001) Measurement of patient satisfaction as an outcome of regional anesthesia and analgesia: a systematic review. Reg Anesth Pain Med 26(3):196-208.
29. Frölich MA, Zhang K, Ness TJ (2013) Effect of sedation on pain perception. Anesthesiology 118(3): 611-621.

30. Estebe JP, Le Naoures A, Chemaly L, Ecoffey C (2000) Tourniquet pain in a volunteer study: effect of changes in cuff width and pressure. Anaesthesia 55(1): 21-26.

31. Fitzgibbons PG, DiGiovanni C, Hares S, Akelman E (2012) Safe tourniquet use: a review of the evidence. J Am Acad Orthop Surg 20(5): 310-319.

32. Drolet BC, Okhah Z, Phillips BZ, Christian BP, Akelman E (2014) Evidence for safe tourniquet use in 500 consecutive upper extremity procedures. Hand 9(4): 494-498.

\section{Your next submission with Juniper Publishers will reach you the below assets}

- Quality Editorial service

- Swift Peer Review

- Reprints availability

- E-prints Service

- Manuscript Podcast for convenient understanding

- Global attainment for your research

- Manuscript accessibility in different formats

( Pdf, E-pub, Full Text, Audio)

- Unceasing customer service

Track the below URL for one-step submission https://juniperpublishers.com/online-submission.php 